\title{
Antimicrobial Susceptibility, Biochemical Characterization and Molecular Typing of Biofield Treated Klebsiella pneumoniae
}

\author{
Mahendra Kumar Trivedi ${ }^{1}$, Alice Branton ${ }^{1}$, Dahryn Trivedi ${ }^{1}$, Mayank Gangwar ${ }^{2}$ and Snehasis Jana ${ }^{2^{*}}$ \\ ${ }^{1}$ Trivedi Global Inc., 10624 S Eastern Avenue Suite A-969, Henderson, NV 89052, USA \\ ${ }^{2}$ Trivedi Science Research Laboratory Pvt. Ltd., Hall-A, Chinar Mega Mall, Chinar Fortune City, Madhya Pradesh, India
}

"Corresponding Author: Dr. Snehasis Jana, Trivedi Science Research Laboratory Pvt. Ltd., Hall-A, Chinar Mega Mall, Chinar Fortune City, Hoshangabad Rd., Bhopal-462026, Madhya Pradesh, India, Tel: +91-755-6660006; E-mail: publication@trivedisrl.com

Received date: September 15, 2015; Accepted date: September 22, 2015; Published date: September 25, 2015

Copyright: ( 2015 Trivedi MK, et al. This is an open-access article distributed under the terms of the Creative Commons Attribution License, which permits unrestricted use, distribution, and reproduction in any medium, provided the original author and source are credited.

\begin{abstract}
Pathogenic isolates of Klebsiella pneumoniae (K. pneumoniae), particularly the extended-spectrum $\beta$-lactamase (ESBL) producing strains, are mostly associated with the failure of antibiotic therapy in nosocomial infections. The present work was designed to evaluate the impact of Mr. Trivedi's biofield energy treatment on phenotypic and genotypic characteristics of $K$. pneumoniae. The strain of $K$. pneumoniae bearing ATCC 15380 (American Type Culture Collection) was procured from the Bangalore Genei, in sealed pack and divided into control and treated groups. Treated group was subjected to Mr. Trivedi's biofield energy treatment and analyzed for the antimicrobial susceptibility, minimum inhibitory concentration (MIC), biochemical reactions, and biotyping using automated MicroScan Walk-Away ${ }^{\circledR}$ system. Further, the effect of biofield treatment was also evaluated using Random Amplified Polymorphic DNA (RAPD) in order to determine their epidemiological relatedness and genetic characteristics of biofield treated $K$. pneumoniae samples. The antimicrobial susceptibility results showed an improve sensitivity (i.e. from intermediate to susceptible) of ampicillin/sulbactam and chloramphenicol, while altered sensitivity of cephalothin (i.e. from susceptible to intermediate) was also reported as compared to the control sample. The MIC value showed two-fold decrease in MIC value of ampicillin/sulbactam (i.e. $16 / 8$ to $\leq 8 / 4 \mu \mathrm{g} / \mathrm{mL}$ ) and chloramphenicol (i.e. 16 to $\leq 8 \mu \mathrm{g} / \mathrm{mL}$ ) as compared to the control. The cephalothin showed two-folds change (i.e. $\leq 8$ to $16 \mu \mathrm{g} / \mathrm{mL}$ ) in the MIC value as compared with the control. Biofield treatment showed $9.09 \%$ alterations in biochemical reactions followed by a change in biotype number $(7774$ 4272) in the treated group with respect to the control $(77744274)$. Genetic fingerprinting was performed on control and treated samples using RAPD-PCR biomarkers, which showed an average range of 11 to $15 \%$ of polymorphism among the treated samples with respect to the control. These results suggested that Mr. Trivedi's biofield energy treatment has a significant impact on K. pneumoniae.
\end{abstract}

Keywords: Klebsiella pneumoniae; Biofield energy treatment; Antibiogram, Biochemical reactions, Polymorphism; Random Amplified Polymorphic DNA.

\section{Abbreviations:}

CAM: Complementary and Alternate Medicine; NHIS: National Health Interview Survey; NCHS: National Center for Health Statistics; ATCC: American Type Culture Collection; MIC: Minimum Inhibitory Concentration; MEGA: Molecular Evolutionary Genetics Analysis; NBPC 30: Negative Breakpoint Combo Panel 30; RAPD: Random Amplified Polymorphic DNA; PCR: Polymerase chain reaction; ESBL: Extended Spectrum $\beta$-Lactamase

\section{Introduction}

The increased medical practice for antibiotic usage creates selection pressure and results emergence of nosocomial pathogens. Klebsiella pneumoniae ( $K$. pneumoniae) is a Gram-negative, facultative anaerobic and rod-shaped bacterium of the Enterobacteriaceae family. It is regarded as an opportunistic pathogen that is associated with the hospital-acquired urinary tract infections, septicemia, pneumonia, and soft tissue infections [1]. $K$. pneumoniae is responsible for the nosocomial outbreaks worldwide, due to its ability to spread rapidly in the hospital environment [2], and results in high morbidity and mortality [3]. It has acquired resistance against extended-spectrum cephalosporins and penicillins, due to the production of extendedspectrum $\beta$-lactamases (ESBLs) [4].

Multidrug combination therapy and some alternate treatment options are required to control the infections associated with this microorganism. Due to the associated side effects and failure of drug treatment therapy, alternate and complementary therapy approach are the preferred treatment strategies. Recently, an alternate treatment approach using healing therapy or therapeutic touch known as biofield energy treatment, which has been widely reported in various research field. The biofield therapies (putative energy fields) were reported to alter the sensitivity of antimicrobial against treated microorganism [5], inhibits the growth of bacterial cultures [6], effect on in vitro cells, tissues [7], animals [8], and the clinical effects such as hematologic [9], immunologic effects [10], healing rates of wounds [11], etc. Biofield is the name given to the electromagnetic field that permeates and surrounds living organisms [12]. It is referred as the biologically produced electromagnetic and subtle energy field that provides regulatory and communication functions within the human organism. Specific environmental frequencies, are absorbed by the different biomolecules, due to changes in the movements of component parts. Therefore, the human or any living object, not only radiate but also absorb and respond to these frequencies [13]. Mr. Mahendra Kumar Trivedi is well known biofield treatment practitioners, and his unique biofield energy treatment is known as The Trivedi Effect. Mr. Trivedi's 
biofield energy treatment has been well known and studied in the field of materials science research [14 -16], agricultural science research $[17,18]$, and microbiology research $[19,20]$.

Due to the clinical importance of $K$. pneumoniae and outstanding results of biofield treatment, the present study was designed to evaluate the impact of $\mathrm{Mr}$. Trivedi's biofield energy treatment on $K$. pneumoniae with respect to the antimicrobial susceptibility, biochemical study, and biotype number. Further, in order to study the phenotypic characteristics of biofield treated $K$. pneumoniae, molecular typing using arbitrary amplification of polymorphic DNA sequences, termed as random amplified polymorphic DNA (RAPD) analysis was used [21]. RAPD is a preferred technique used in different studies for typing and discriminating the epidemiology of microorganism [22]. RAPD has an advantage over other traditional phenotypic typing methods as it is rapid, relatively inexpensive and technically feasible [23]. The aim of this study was to evaluate the impact of Mr. Trivedis biofield energy treatment on $K$. pneumoniae with respect to antibiogram characteristics and genotyping using RAPD of the organism.

\section{Materials and Methods}

K. pneumoniae ATCC 15380 [American Type Culture Collection] was procured from Bangalore Genei, in sealed pack, and stored as per the recommended storage conditions for further use. The antimicrobial susceptibility, minimum inhibitory concentration (MIC), biochemical reactions, and biotype number were evaluated using automated MicroScan Walk-Away system (Dade Behring Inc., West Sacramento, CA) using Negative Breakpoint Combo 30 (NBPC 30) panel. RAPD was carried out using Ultrapure Genomic DNA Prep Kit; Cat KT 83 (Bangalore Genei, India). All the tested antimicrobials, biochemicals, media, and reagents were procured from Sigma-Aldrich, India.

\section{Biofield treatment modalities}

$K$. pneumoniae strain was divided into two groups i.e. control and treated. The treated group was in sealed pack and handed over to $\mathrm{Mr}$. Trivedi for the biofield energy treatment under laboratory conditions. Mr. Trivedi provided the treatment through his energy transmission process to the treated group that includes bioenergy emission of certain wavelength, which has the ability to do the changes in the microbes without touching the sample. Mr. Trivedi's unique energy treatment is known as The Trivedi Effect. Mr. Trivedi visited the laboratory individually over a period of treatment and for control experiments, nobody entered the experimental room during the treatment period. Whilst handing over these cultures to Mr. Trivedi for treatment purposes, optimum precautions were taken to avoid contamination. After treatment, control and treated groups were assessed on day 10 for the antimicrobial susceptibility, minimum inhibitory concentration (MIC), biochemical reactions, biotype, and genotyping using RAPD analysis. The result of treated sample was compared with respect to the control.

\section{Investigation of antimicrobial susceptibility assay}

Investigation of antimicrobial susceptibility of $K$. pneumoniae was carried out with the help of automated instrument, MicroScan WalkAway using Negative Breakpoint Combo 30 (NBPC30) panel as per the manufacturer's instructions. The panel was allowed to equilibrate to room temperature prior to rehydration. All opened panel were used on the same day. The tests were carried out on MicroScan, which were miniaturized of the broth dilution susceptibility test that had been dehydrated. Briefly, $100 \mu \mathrm{L}$ of the standardized suspension of $K$. pneumoniae was pipetted into $25 \mathrm{~mL}$ of inoculum water using pluronic and inverted 8-10 times and inoculated, rehydrated, and then subjected to incubation for 16 hours at $35^{\circ} \mathrm{C}$. Rehydration and inoculation were performed using the RENOK $^{\circ}$ system with inoculators-D (B1013-4). The detailed experimental procedures and conditions were followed as per the manufacturer's instructions. Briefly, after inoculation and rehydration with a standardized suspension of $K$. pneumoniae, it was incubated at $35^{\circ} \mathrm{C}$ for 16 hours. MIC and a qualitative susceptibility like susceptible (S), intermediate (I), and resistant (R) were determined by observing the lowest antimicrobial concentration showing growth inhibition [24].

\section{Biochemical studies}

The biochemical reactions of $K$. pneumoniae were determined by MicroScan Walk-Away where, interpretation of biochemical reactions for microbial identification of Gram-negative organisms [24].

\section{Biotype number}

The biotype number of $K$. pneumoniae was determined by MicroScan Walk-Away processed panel data utilizing data of biochemical reactions [24].

\section{Random Amplified Polymorphic DNA (RAPD) analysis}

Three series of inoculums (one for control and other two for treatment named as treated $\mathrm{A}$ and $\mathrm{B}$ ) were prepared from $K$. pneumoniae sample. Two inoculums (treated samples A and B) were subjected to Mr. Trivedi's biofield energy treatment. Whilst handing over treated groups to Mr. Trivedi for biofield treatment, optimum precautions were taken to avoid the contamination. After that, the treated samples (A and B) were sub-cultured by taking $1 \%$ inoculum and inoculated to fresh $5 \mathrm{~mL}$ medium and labeled as treatment A-1 and treatment B-1 respectively. Control and treated samples were incubated at $37^{\circ} \mathrm{C}$ with $160 \mathrm{rpm}$ for $18 \mathrm{~h}$. Subsequently, the cultures were spun down, and genomic DNA was isolated for control and treated samples using the genomic DNA Prep Kit (Bangalore Genei, India). The RAPD was performed with all samples of $K$. pneumoniae using five RAPD primers, which were labelled as RBA 5A, RBA 10A, RBA 15A, RBA 21A, and RBA 22A. The PCR mixture contained $2.5 \mu \mathrm{L}$ each of buffer, $4.0 \mathrm{mM}$ each of dNTP, $2.5 \mu \mathrm{M}$ each of primer, $5.0 \mu \mathrm{L}$ each of genomic DNA, $2 \mathrm{U}$ each of Taq polymerase, $1.5 \mu \mathrm{L}$ of $\mathrm{MgCl}_{2}$ and $9.5 \mu \mathrm{L}$ of nuclease-free water in a total of $25 \mu \mathrm{L}$ mixture. PCR amplification protocol was followed with initial denaturation at $94^{\circ} \mathrm{C}$ for $7 \mathrm{~min}$, followed by 8 cycles of denaturation at $94^{\circ} \mathrm{C}$ for $1 \mathrm{~min}$, annealing at $35^{\circ} \mathrm{C}$ for $1 \mathrm{~min}$, and extension at $72^{\circ} \mathrm{C}$ for $2 \mathrm{~min}$; and 35 cycle of denaturation at $94^{\circ} \mathrm{C}$ for $1 \mathrm{~min}$, annealing at $38^{\circ} \mathrm{C}$ for $1 \mathrm{~min}$, and extension at $72^{\circ} \mathrm{C}$ for $1.5 \mathrm{~min}$; and the final extension at $72^{\circ} \mathrm{C}$ for 7 min. Amplified PCR products $(12 \mu \mathrm{L})$ from all the samples (control and treated) were separated on $1.5 \%$ agarose gels at 75 volts, stained with ethidium bromide and visualized under UV illumination [25].

The percentage of polymorphism was calculated using following equation-

\section{Percent polymorphism $=\mathrm{A} / \mathrm{B} \times 100$;}

Where, $\mathrm{A}=$ number of polymorphic bands in treated sample; and $\mathrm{B}$ $=$ number of polymorphic bands in control. 
Citation: Trivedi MK, Branton A, Trivedi D, Gangwar M, Jana S (2015) Antimicrobial Susceptibility, Biochemical Characterization and Molecular Typing of Biofield Treated Klebsiella pneumoniae. J Health Med Inform 6: 206. doi:10.4172/2157-7420.1000206

Page 3 of 7

\section{Results and Discussion}

\section{Antimicrobial susceptibility assay}

The results of biofield treatment on $K$. pneumoniae with respect to antimicrobials susceptibility pattern and MIC are summarized in Table 1 and 2 , respectively.

\begin{tabular}{|c|c|c|c|}
\hline S. No. & Antimicrobial & Control & Treated \\
\hline 1 & Amikacin & $\mathrm{S}$ & $\mathrm{S}$ \\
\hline 2 & Amoxicillin/k-clavulanate & $\mathrm{S}$ & $\mathrm{S}$ \\
\hline 3 & Ampicillin/sulbactam & 1 & $\mathrm{~s}$ \\
\hline 4 & Ampicillin & $\mathrm{R}$ & $\mathrm{R}$ \\
\hline 5 & Aztreonam & $\mathrm{S}$ & $S$ \\
\hline 6 & Cefazolin & $\mathrm{S}$ & $\mathrm{s}$ \\
\hline 7 & Cefepime & $\mathrm{S}$ & S \\
\hline 8 & Cefotaxime & $S$ & $S$ \\
\hline 9 & Cefotetan & $\mathrm{S}$ & $S$ \\
\hline 10 & Cefoxitin & $S$ & $S$ \\
\hline 11 & Ceftazidime & $S$ & $S$ \\
\hline 12 & Ceftriaxone & $\mathrm{s}$ & $\mathrm{s}$ \\
\hline 13 & Cefuroxime & $S$ & $S$ \\
\hline 14 & Cephalothin & $\mathrm{S}$ & 1 \\
\hline 15 & Chloramphenicol & 1 & $S$ \\
\hline 16 & Ciprofloxacin & $\mathrm{S}$ & S \\
\hline 17 & Gatifloxacin & $\mathrm{S}$ & $\mathrm{S}$ \\
\hline 18 & Gentamicin & $\mathrm{S}$ & S \\
\hline 19 & Imipenem & $\mathrm{S}$ & S \\
\hline 20 & Levofloxacin & S & $S$ \\
\hline 21 & Meropenem & $\mathrm{S}$ & $S$ \\
\hline 22 & Moxifloxacin & $\mathrm{S}$ & $S$ \\
\hline 23 & Piperacillin/tazobactam & $\mathrm{S}$ & $\mathrm{S}$ \\
\hline 24 & Piperacillin & I & 1 \\
\hline 25 & Tetracycline & $\mathrm{S}$ & $S$ \\
\hline 26 & Ticarcillin/k-clavulanate & S & $S$ \\
\hline 27 & Tobramycin & S & S \\
\hline 28 & Trimethoprim/sulfamethoxazole & S & S \\
\hline
\end{tabular}

Table 1: Effect of biofield treatment on $K$. pneumoniae for its antimicrobial susceptibility

\begin{tabular}{|l|l|l|l|}
\hline S. No. & Antimicrobial & Control & Treated \\
\hline
\end{tabular}

\begin{tabular}{|c|c|c|c|}
\hline 1 & Amikacin & $\leq 16$ & $\leq 16$ \\
\hline 2 & Amoxicillin/k-clavulanate & $\leq 8 / 4$ & $\leq 8 / 4$ \\
\hline 3 & Ampicillin/sulbactam & $16 / 8$ & $\leq 8 / 4$ \\
\hline 4 & Ampicillin & $>16$ & $>16$ \\
\hline 5 & Aztreonam & $\leq 8$ & $\leq 8$ \\
\hline 6 & Cefazolin & $\leq 8$ & $\leq 8$ \\
\hline 7 & Cefepime & $\leq 8$ & $\leq 8$ \\
\hline 8 & Cefotaxime & $\leq 8$ & $\leq 8$ \\
\hline 9 & Cefotetan & $\leq 16$ & $\leq 16$ \\
\hline 10 & Cefoxitin & $\leq 8$ & $\leq 8$ \\
\hline 11 & Ceftazidime & $\leq 8$ & $\leq 8$ \\
\hline 12 & Ceftriaxone & $\leq 8$ & $\leq 8$ \\
\hline 13 & Cefuroxime & $\leq 4$ & $\leq 4$ \\
\hline 14 & Cephalothin & $\leq 8$ & 16 \\
\hline 15 & Chloramphenicol & 16 & $\leq 8$ \\
\hline 16 & Ciprofloxacin & $\leq 1$ & $\leq 1$ \\
\hline 17 & ESBL-a Scrn & $\leq 4$ & $\leq 4$ \\
\hline 18 & ESBL-b Scrn & $\leq 1$ & $\leq 1$ \\
\hline 19 & Gatifloxacin & $\leq 2$ & $\leq 2$ \\
\hline 20 & Gentamicin & $\leq 4$ & $\leq 4$ \\
\hline 21 & Imipenem & $\leq 4$ & $\leq 4$ \\
\hline 22 & Levofloxacin & $\leq 2$ & $\leq 2$ \\
\hline 23 & Meropenem & $\leq 4$ & $\leq 4$ \\
\hline 24 & Moxifloxacin & $\leq 2$ & $\leq 2$ \\
\hline 25 & Nitrofurantoin & $\leq 32$ & $\leq 32$ \\
\hline 26 & Norfloxacin & $\leq 4$ & $\leq 4$ \\
\hline 27 & Piperacillin/tazobactam & $\leq 16$ & $\leq 16$ \\
\hline 28 & Piperacillin & 64 & 64 \\
\hline 29 & Tetracycline & $\leq 4$ & $\leq 4$ \\
\hline 30 & Ticarcillin/k-clavulanate & $\leq 16$ & $\leq 16$ \\
\hline 31 & Tobramycin & $\leq 4$ & $\leq 4$ \\
\hline 32 & Trimethoprim/sulfamethoxazole & $\leq 2 / 38$ & $\leq 2 / 38$ \\
\hline
\end{tabular}

Table 2: Minimum inhibitory concentration (MIC) of tested antimicrobials against $K$. pneumoniae

The antimicrobial sensitivity result of three antimicrobials namely ampicillin/sulbactam, cephalothin, and chloramphenicol showed the alteration after biofield treatment with respect to control among 
Page 4 of 7

twenty-eight tested antimicrobials. The sensitivity of ampicillin/ sulbactam and chloramphenicol was improved i.e. from intermediate (I) to susceptible (S), while cephalothin showed an altered sensitivity nature from $S$ to $I$. Other tested antimicrobials did not show any alterations of sensitivity pattern as compared to the control.

MIC results were well supported with antimicrobial sensitivity data, as ampicillin/sulbactam and chloramphenicol showed decrease value of MIC after the biofield treatment. Ampicillin/sulbactam (i.e. 16/8 to $\leq 8 / 4 \mu \mathrm{g} / \mathrm{mL}$ ) and chloramphenicol (i.e. 16 to $\leq 8 \mu \mathrm{g} / \mathrm{mL}$ ) showed two folds change in MIC values as compared to the control. Cephalothin showed an alteration in MIC value i.e. from $\leq 8$ to $16 \mu \mathrm{g} / \mathrm{mL}$ after biofield treatment. The rest of the tested antimicrobials did not show any alteration in MIC values with respect to the control.

Efficacy of sulbactam, a $\beta$-lactamase inhibitor, in combination with ampicillin, was well reported and a preferred treatment option against $\beta$-lactam-resistant $K$. pneumoniae infections. According to Hoffman et al. the combination of ampicillin/sulbactam was found to have synergistic effects, which significantly decreased the severity of pneumonia. Bronchoalveolar lavage cytologic findings, and extent of macroscopic lesions in lung tissue of the noninoculated regions were reported as compared to the individual ampicillin or sulbactam [26]. The resistance pattern of ampicillin against $K$. pneumoniae is because of two types of chromosomal $\beta$-lactamase enzymes being SHV- 1 and LEN-1 [27], and results suggest that biofield treatment might alter these enzymes and alter the sensitivity pattern. Biofield treatment on $K$. pneumoniae has improved the sensitivity profile of ampicillin/ sulbactam and showed decreased MIC value by two-folds, which might be useful in the future treatment strategy against pneumoniae lung infection. Multi-drug therapies are another approach against $\beta$ lactamase producing strain of $K$. pneumoniae, as synergy has been frequently reported in vitro between $\beta$-lactams and aminoglycosides. According to Jones, a synergistic effect was frequently reported in a combination of ertapenem and ciprofloxacin [28]. Besides synergistic effect, antibiotics such as amikacin, gatifloxacin, gentamicin, and chloramphenicol are the preferred drug of choice with respect to cost, side effects and many other factors in $K$. pneumoniae associated infections [29]. Mr. Trivedi's biofield energy treatment on $K$. pneumoniae showed improved sensitivity pattern of chloramphenicol and simultaneously decreased the MIC value as compared to the control. $\beta$-lactamases are enzymes that inactivates the $\beta$-lactam containing antibiotic which is present in almost all Gram-negative bacilli such as E. coli and Klebsiella spp. [30]. Biofield treatment might alter the production of these enzymes which may result in the improved sensitivity of antimicrobials.

\section{Organism identification by biochemical reactions}

Biochemical study results of control and biofield treated groups are summarized in Table 3.

\begin{tabular}{|l|l|l|l|l|}
\hline S. No. & Code & Biochemical & Control & Treated \\
\hline 1 & ACE & Acetamide & - & - \\
\hline 2 & ADO & Adonitol & + & + \\
\hline 3 & ARA & Arabinose & + & + \\
\hline 4 & ARG & Arginine & - & - \\
\hline 5 & CET & Cetrimide & - & - \\
\hline
\end{tabular}

\begin{tabular}{|c|c|c|c|c|}
\hline 6 & CF8 & Cephalothin & - & + \\
\hline 7 & CIT & Citrate & + & + \\
\hline 8 & CL4 & Colistin & + & - \\
\hline 9 & ESC & Esculin hydrolysis & + & + \\
\hline 10 & FD64 & Nitrofurantoin & - & - \\
\hline 11 & GLU & Glucose & + & + \\
\hline 12 & $\mathrm{H} 2 \mathrm{~S}$ & Hydrogen sulfide & - & - \\
\hline 13 & IND & Indole & - & - \\
\hline 14 & INO & Inositol & + & + \\
\hline 15 & K4 & Kanamycin & - & - \\
\hline 16 & LYS & Lysine & + & + \\
\hline 17 & MAL & Malonate & + & + \\
\hline 18 & MEL & Melibiose & + & + \\
\hline 19 & NIT & Nitrate & + & - \\
\hline 20 & OF/G & $\begin{array}{l}\text { Oxidation-fermentation/ } \\
\text { glucose }\end{array}$ & + & + \\
\hline 21 & ONPG & Galactosidase & + & + \\
\hline 22 & ORN & Ornithine & - & - \\
\hline 23 & OXI & Oxidase & - & - \\
\hline 24 & P4 & Penicillin & + & + \\
\hline 25 & RAF & Raffinose & + & + \\
\hline 26 & RHA & Rhamnose & + & + \\
\hline 27 & SOR & Sorbitol & + & + \\
\hline 28 & SUC & Sucrose & + & + \\
\hline 29 & TAR & Tartrate & - & - \\
\hline 30 & TDA & Tryptophan deaminase & - & - \\
\hline 31 & TO4 & Tobramycin & - & - \\
\hline 32 & URE & Urea & + & + \\
\hline 33 & VP & Voges-Proskauer & - & - \\
\hline
\end{tabular}

Table 3: Effect of biofield treatment on $K$. pneumoniae to the vital processes occurring in living organisms -: negative; +: positive.

The results showed overall $9.09 \%$ of tested biochemical altered reactions as compared to the control. The colistin and nitrate biochemical showed negative reaction i.e. from $(+)$ positive to (-) negative as compared to the control. Cephalothin showed positive reaction i.e. from (-) negative to $(+)$ positive reaction. The rest of tested biochemicals did not show any alteration in their reaction pattern after biofield treatment. The biochemical reactions of control $K$. pneumoniae were well supported with literature data [31]. 
Citation: Trivedi MK, Branton A, Trivedi D, Gangwar M, Jana S (2015) Antimicrobial Susceptibility, Biochemical Characterization and Molecular Typing of Biofield Treated Klebsiella pneumoniae. J Health Med Inform 6: 206. doi:10.4172/2157-7420.1000206

Page 5 of 7

\section{Organism identification by biotype number}

Based on the biochemical results, alteration in biotype number was also observed in the biofield treated $K$. pneumoniae as compared to the control. The control group showed biotype number as 7774 4274, while after treatment altered biotype number was reported as 77744272. However, no change in organism was reported after biofield treatment with respect to the control. Our research group recently reported the significant alterations in biochemical reactions followed by the change in biotype number that was also supported with published data $[19,20]$. Biofield treatment might alter some enzymatic reactions in $K$. pneumoniae, which resulted in alterations in characteristic biochemical reactions and biotype number.

\section{Random Amplified Polymorphic DNA (RAPD) analysis}

RAPD has been used as a genotyping tool to that is being used to correlate the genetic similarity or mutations between species of $K$. pneumoniae [32]. DNA fingerprinting analysis of the control and treated $K$. pneumoniae was identified on the basis of their different and discriminative RAPD patterns. The simplicity and wide applicability of RAPD analysis mainly depend on the use of short nucleotide primers, which were unrelated to known DNA sequences of the target organism [21]. DNA polymorphism can be efficiently detected using the PCR primers and identify the inter-strain variations among species in the treated samples. The degree of relatedness and genetic mapping can be correlated between similar or different treated sample species [33].

In this experiment, DNA fingerprinting of control and treated samples using RAPD are shown in Figure 1.

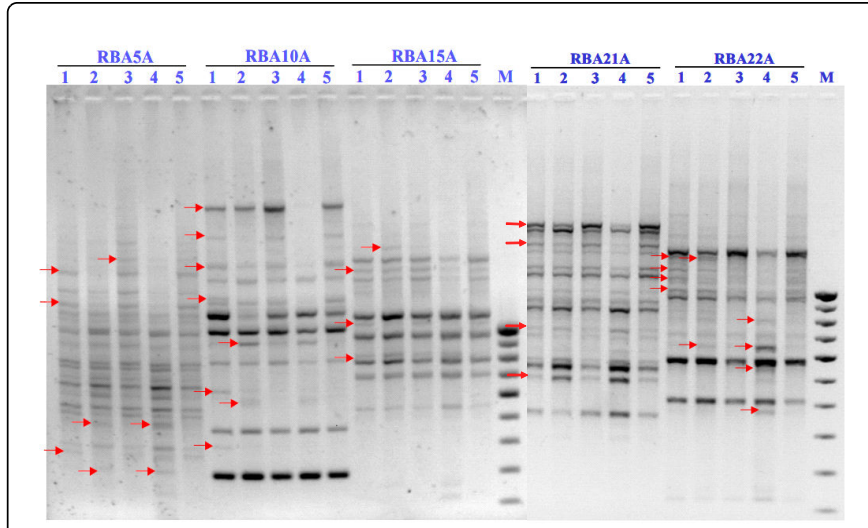

Figure 1: Random amplified polymorphic-DNA fragment patterns of $K$. pneumoniae generated using five RAPD primers, RBA 5A, RBA 10A, RBA 15A, RBA 21A and RBA 22A. 1: Control; 2: Treated A; 3: Treated A-1; 4: Treated B; 5: Treated B-1; M: 100 bp DNA Ladder.

The polymorphic bands are marked by arrows in the gel image. The RAPD patterns of treated samples showed some unique, dissimilar, common, and polymorphic patterns. DNA polymorphism among the different treated samples compared with the control were analyzed and presented in Table 4.

\begin{tabular}{|c|c|c|c|c|c|c|c|c|c|}
\hline \multirow{2}{*}{ S. No. } & \multirow{2}{*}{ Primer } & \multirow{2}{*}{$\begin{array}{l}\text { Nucleotide sequence } \\
\left(5^{\prime}-3^{\prime}\right)\end{array}$} & \multirow{2}{*}{$\begin{array}{l}\text { Total no. of } \\
\text { polymorphic bands }\end{array}$} & \multirow{2}{*}{$\begin{array}{l}\text { Common bands in } \\
\text { control and treated }\end{array}$} & \multicolumn{5}{|c|}{ Unique band } \\
\hline & & & & & Control & TSA & TSA-1 & TSB & TSB-1 \\
\hline 1 & RBA 5A & GTTTCGCTCC & 18 & 11 & 1 & 2 & 1 & 1 & 2 \\
\hline 2 & RBA 10A & GTGGATCCGA & 15 & 5 & 3 & 1 & 0 & 0 & 0 \\
\hline 3 & RBA 15A & GCGATCCCCA & 12 & 8 & 1 & 1 & 0 & 0 & 0 \\
\hline 4 & RBA 21A & CCGCAGCCAA & 15 & 13 & 0 & 0 & 0 & 0 & 0 \\
\hline 5 & RBA 22A & AAGAGCCCGT & 14 & 5 & 1 & 1 & 0 & 2 & 0 \\
\hline
\end{tabular}

Table 4: DNA polymorphism of $K$. pneumoniae analyzed by random amplified polymorphic DNA (RAPD) analysis, TSA: treated sample A; TSA-1: treated sample A-1; TSB: treated sample B; TSB-1: treated sample B-1.

The level of polymorphism between control and treated samples (A, $\mathrm{A} 1, \mathrm{~B}$, and B1) are summarized in Table 5.

\begin{tabular}{|c|c|c|c|c|c|c|c|c|}
\hline Primer & $\mathrm{C}$ and TSA & $\mathrm{C}$ and TSA-1 & $\mathrm{C}$ and TSB & $\mathrm{C}$ and TSB-1 & TSA and TSA-1 & TSB and TSB-1 & TSA and TSB & TSA -1 and TSB- 1 \\
\hline RBA 5A & $18 \%$ & $12 \%$ & $12 \%$ & $18 \%$ & $18 \%$ & $18 \%$ & $6 \%$ & $6 \%$ \\
\hline RBA 10A & $30 \%$ & $15 \%$ & $15 \%$ & $23 \%$ & $10 \%$ & $0 \%$ & $15 \%$ & $8 \%$ \\
\hline RBA $15 A$ & $18 \%$ & $27 \%$ & $27 \%$ & $9 \%$ & $11 \%$ & $0 \%$ & $9 \%$ & $15 \%$ \\
\hline RBA $21 \mathrm{~A}$ & $0 \%$ & $6 \%$ & $0 \%$ & $0 \%$ & $0 \%$ & $0 \%$ & $0 \%$ & $6 \%$ \\
\hline RBA 22A & $13 \%$ & $6 \%$ & $20 \%$ & $6 \%$ & $10 \%$ & $20 \%$ & $5 \%$ & $0 \%$ \\
\hline
\end{tabular}




\begin{tabular}{|l|l|l|l|l|l|l|l|l|}
\hline Average polymorphism & $15 \%$ & $13 \%$ & $14 \%$ & $11 \%$ & $9 \%$ & $7 \%$ & $7 \%$ & $7 \%$ \\
\hline
\end{tabular}

Table 5: Level of polymorphism between control and treated $K$. pneumoniae samples. C: Control; TSA: treated sample A; TSA-1: treated sample A-1; TSB: treated sample B; TSB-1: treated sample B-1.

The level of polymorphism was found in an average range of 11 to $15 \%$ in the treated samples as compared to control after the biofield treatment. The highest change in DNA sequence was observed in treated samples with RBA $10 \mathrm{~A}$ primer as compared to control; whereas no change was found in treated sample with RBA 21A primer as compared to control. Thus, results indicates that treatment samples has genetic variability among organism. RAPD also explains the relevant degree of genetic diversity, however this technique has the potential to detected genetic polymorphism throughout the genome [34].

Biofield energy as the complementary medicine is well documented and considered as alternate medicine approach worldwide. According to the report of National Health Interview Survey (NHIS), conducted by the Centers for Disease Control and Prevention's (CDC) and National Center for Health Statistics (NCHS) till 2007, energy medicine was practiced almost 4 out of 10 adults in the past 12 months [35]. Current experiment was designed to demonstrate the impact of Mr. Trivedi's biofield treatment on $K$. pneumoniae for its antimicrobial susceptibility testing. Further, the molecular methods was performed to study the genetic alterations and similarities using RAPD sequencing methods. Increased infection of $K$. pneumoniae and other Gram-negative pathogen associated with nosocomial infections have become a global health problem. Results suggest that biofield treatment on microorganism can alter the in vitro sensitivity of the antimicrobials and it might be correlated with acetylation of antimicrobials that may happen via active drug efflux mechanism. Increased incidence of nosocomial infections and broad resistance against broad spectrum antibiotics would be a serious global threat. Mr. Trivedi's biofield treatment showed a significant decrease in MIC values of ampicillin/sulbactam and chloramphenicol along with improved sensitivity, which suggested an alteration at enzymatic/ genetic level that may modify ligand-receptor interaction. Hence a cascade of intra-cellular signals may be initiated, accelerated or inhibited [36], after biofield treatment on pathogenic microbes. Further, biofield treatment on $K$. pneumoniae, possible involve alterations at receptor level due to energy transfer via. biofield treatment, which may change the receptor drug interactions, which in turn alter the internal state of the microbe. However, it was reported that electromagnetic fields might alter the transmembrane concentration of cell, and will alter the receptor protein molecule. Biofield treatment might alter the receptor interaction, and results in altered antibiogram of $K$. pneumoniae with respect to the control [37].

\section{Conclusion}

In summary, it can be concluded that Mr. Trivedi's biofield energy treatment on $K$. pneumoniae has improved the antimicrobial sensitivity and decreased the MIC value by two folds in case ampicillin/sulbactam and chloramphenicol. Cephalothin showed altered antibiogram after biofield treatment as compared to the control. The biochemical study results showed the alteration of biochemical reactions of cephalothin, colistin, and nitrate, followed by change in the biotype number (7774 4272) after biofield treatment as compared to the control biotype (7774 4274). Using RAPD markers, the biofield treated samples were characterized and showed interspecific polymorphic relationship with $K$. pneumoniae after biofield treatment. Overall, it seems that Mr. Trivedi's unique biofield energy treatment on pathogenic microbes might be used as an alternate approach to alter the antimicrobial sensitivity.

\section{Acknowledgement}

This work was supported by Trivedi Science"', Trivedi Master Wellness and Trivedi Testimonials. Authors acknowledge the generosity and cooperation of all participating members from $\mathrm{PD}$ Hinduja National Hospital and MRC, Mumbai, Microbiology Lab for conduction antimicrobial studies. Authors are thankful to Bangalore Genei Private Limited, for conducting RAPD analysis.

\section{References}

1. Podschun R, Ullmann U (1998) Klebsiella spp. as nosocomial pathogens: Epidemiology, taxonomy, typing methods, and pathogenicity factors. Clin Microbiol Rev 11: 589-603.

2. Chetoui H, Delhalle E, et al. (1999) Epidemiological typing of extended spectrum b-lactamase-producing Klebsiella pneumoniae isolates by pulsed-field gel electrophoresis and antibiotic susceptibility patterns. Res Microbiol 150: 265-272.

3. Vernet V, Philippon A, et al. (1995) Virulence factors (aerobactin and mucoid phenotype) in Klebsiella pneumoniae and E. coli blood culture isolates. FEMS Microbiol Lett 130: 51-57.

4. Corkill JE, Cuevas LE, Guegel RQ, Greensill J, Hart CA (2001) SHV-27, a novel cefotaxime-hydrolysing beta-lactamase, identified in Klebsiella pneumoniae isolates from a Brazilian hospital. J Antimicrob Chemother 47: 463-465.

5. Trivedi MK, Patil S, Shettigar H, Bairwa K, Jana S (2015) Phenotypic and biotypic characterization of Klebsiella oxytoca: An impact of biofield treatment. J Microb Biochem Technol 7: 203-206.

6. Rubik B, Brooks AJ, Schwartz GE (2006) In vitro effect of Reiki treatment on bacterial cultures: Role of experimental context and practitioner wellbeing. J Altern Complement Med 12: 7-13.

7. Chein CH, Tsuei JJ, Lee SC, Huang YC, Wei YH (1991) Effect of emitted bioenergy on biochemical function of cells. Am J Chin Med 19: 285-292.

8. Mo Z, Chen KW, Ou W, Li M (2003) Benefits of external qigong therapy on morphine-abstinent mice and rats. J Altern Complement Med 9: 827-835.

9. Movaffaghi Z, Hassanpoor M, Farsi M, Hooshmand P, Abrishami F (2006) Effects of therapeutic touch on blood hemoglobin and hematocrit level. J Holist Nurs 24: 41-48.

10. Olson M, Sneed N, et al. (1997) Stress-induced immunosuppression and therapeutic touch. Altern Ther Health Med 3: 68-74.

11. Wirth DP (1990) The effect of none contact therapeutic touch on the healing rate of full thickness dermal wounds. Subtle Energies 1: 1-20.

12. Jain S, Mills PJ (2010) Biofield therapies: Helpful or full of hype? A best evidence synthesis. Int J Behav Med 17: 1-16.

13. Oschman JL (2000) Energy medicine: The scientific base. (2ndedn). Edinburgh: Churchill Livingston.

14. Trivedi MK, Tallapragada RR (2008) A transcendental to changing metal powder characteristics. Met Powder Rep 63: 22-28, 31.

15. Dabhade VV, Tallapragada RR, Trivedi MK (2009) Effect of external energy on atomic, crystalline and powder characteristics of antimony and bismuth powders. Bull Mater Sci 32: 471-479. 
Citation: Trivedi MK, Branton A, Trivedi D, Gangwar M, Jana S (2015) Antimicrobial Susceptibility, Biochemical Characterization and Molecular Typing of Biofield Treated Klebsiella pneumoniae. J Health Med Inform 6: 206. doi:10.4172/2157-7420.1000206

Page 7 of 7

16. Trivedi MK, Nayak G, Patil S, Tallapragada RM, Latiyal O (2015) Studies of the atomic and crystalline characteristics of ceramic oxide nano powders after bio field treatment. Ind Eng Manage 4: 161.

17. Sances F, Flora E, Patil S, Spence A, Shinde V (2013) Impact of biofield treatment on ginseng and organic blueberry yield. Agrivita J Agric Sci 35: 22-29.

18. Lenssen AW (2013) Biofield and fungicide seed treatment influences on soybean productivity, seed quality and weed community. Agricultural Journal 8: 138-143.

19. Trivedi MK, Patil S, Shettigar H, Gangwar M, Jana S (2015) An effect of biofield treatment on multidrug-resistant Burkholderia cepacia: A multihost pathogen. J Trop Dis 3: 167.

20. Trivedi MK, Patil S, Shettigar H, Gangwar M, Jana S (2015) Antimicrobial sensitivity pattern of Pseudomonas fluorescens after biofield treatment. J Infect Dis Ther 3: 222.

21. Williams JG, Kubelik AR, Livak KJ, Rafalski JA, Tingey SV (1990) DNA polymorphisms amplified by arbitrary primers are useful as genetic markers. Nucleic Acids Res 18: 6531-6535.

22. Meunier JR, Grimont PA (1993) Factors affecting reproducibility of random amplified polymorphic DNA fingerprinting. Res Microbiol 144: 373-379.

23. Welsh J, McClelland M (1990) Fingerprinting genomes using PCR with arbitrary primers. Nucleic Acids Res 18: 7213-7218.

24. Fader RC, Weaver E, et al. (2013) Multilaboratory study of the biomic automated well-reading instrument versus MicroScan WalkAway for reading MicroScan antimicrobial susceptibility and identification panels. J Clin Microbiol 51: 1548-1554.

25. Ashayeri-Panah M, Eftekhar F, Ghamsari MM, Parvin M, Feizabadi MM (2013) Genetic profiling of Klebsiella pneumoniae: Comparison of pulsed field gel electrophoresis and random amplified polymorphic DNA. Braz J Microbiol 44: 823-828.

26. Hoffman AM, Viel L, Muckle CA, Yager JS, Staempfli HR (1992) Evaluation of sulbactam plus ampicillin for treatment of experimentally induced Klebsiella pneumoniae lung infection in foals. Am J Vet Res 53: 1059-1067.
27. Haeggman S, Lofdahl S, Burman LG (1997) An allelic variant of the chromosomal gene for class A beta-lactamase K2, specific for Klebsiella pneumoniae, is the ancestor of SHV-1. Antimicrob Agents Chemother 41: 2705-2709.

28. Jones RN (2001) In vitro evaluation of ertapenem (MK-0826), a longacting carbapenem, tested against selected resistant strains. J Chemother 13: 363-376.

29. Kumar AR (2013) Antimicrobial sensitivity pattern of Klebsiella pneumonia isolated from pus from tertiary care hospital and issues related to the rational selection of antimicrobials. J Chem Pharm Res 5: 326-331.

30. Jones RN, Baquero F, Privitera G, Inoue M, Wiedemann B (1997) Inducible $\beta$-lactamase-mediated resistance to third-generation cephalosporins. Clin Microbiol Infect 3: s7-s20.

31. Hansen DS, Aucken HM, Abiola T, Podschun R (2004) Recommended test panel for differentiation of Klebsiella species on the basis of a trilateral interlaboratory evaluation of 18 biochemical tests. J Clin Microbiol 42: 3665-3669.

32. Eisen D, Russel EG, et al. (1995) Random amplified polymorphic DNA and plasmid analysis used in investigation of an outbreak of multiresistant Klebsiella pneumoniae. J Clin Microbiol 33: 713-717.

33. Williams JG, Hanafey MK, Rafalski JA, Tingey SV (1993) Genetic analysis using random amplified polymorphic DNA markers. Methods Enzymol 218: 704-740.

34. Orskov I, Orskov F (1984) Serotyping of Klebsiella. Methods in microbiology. NY: Academic Press, Inc. New York.

35. Barnes PM, Bloom B, Nahin RL (2008) Complementary and alternative medicine use among adults and children: United States, 2007. Natl Health Stat Report 10: 1-23.

36. Hintz KJ, Yount GL, et al. (2003) Bioenergy definitions and research guidelines. Altern Ther Health Med 9: A13-A30.

37. Lindstrom E, Mild KH, Lundgren E (1998) Analysis of the T cell activation signaling pathway during ELF magnetic field exposure, p56 ${ }^{\mathrm{lck}}$ and $[\mathrm{Ca} 2+]$ i-measurements. Bioeletrochem Bioenerg 46: 129-137. 